\title{
PENERAPAN PENDIDIKAN KESEHATAN TENTANG METODE KONTRASEPSI PADA IBU PRIMIPARA DI RUANGAN DAHLIA RUMAH SAKIT DAERAH LIUNKENDAGE TAHUNA SANGIHE
}

\author{
APPLICATION OF HEALTH EDUCATION ABOUT CONTRACEPTIVE METHOD \\ TO PRIMIPAROUS MOTHER IN THE DAHLIA ROOM \\ IN LIUNKENDAGE HOSPITAL TAHUNA SANGIHE
}

\author{
Nur Azizah Usman, Nansy Pangandaheng, Christien Angreni Rambi \\ Program Studi Keperawatan Jurusan Kesehatan Politeknik Negeri Nusa Utara \\ Kampus POLNUSTAR Jl.Kesehatan No.1 Tahuna \\ Email: christienrambi@yahoo.com
}

\begin{abstract}
ABSTRAK: Program keluarga berencana memungkinkan pemerintah untuk menurunkan angka fertilitas dan meningkatkan perbaikan kesehatan, kesejahteraan, hak asasi manusia, dan pendidikan. Di beberapa negara berkembang penggunaan kontrasepsi masih terbatas.Pendidikan kesehatan merupakan salah satu cara untuk meningkatkan pengetahuan tentang alat kontrasepsi. Penelitian ini bertujuan untuk mengetahui gambaran penerapan metode pendidikan kesehatan tentang kontrasepsi pada Ibu primipara di ruangan Dahlia RSD Liun Kendage Tahuna.Desain penelitian menggunakan rancangan deskriptif dengan pendekatan proses keperawatan. Penelitian dilaksanakan pada bulan Mei 2019 dengan subyek penelitian 2 ibu primipara post sectio caesarea. Penelitian menggunakan format pengkajian maternitas dan SAP. Data disajikan secara narasi dan dalam bentuk tabel. Saat dikaji klien tidak tahu tentang kontrasepsi, setelah dilakukan pendidikan kesehatan kedua klien mengetahui metode kontrasepsi. Klien yang pertama memilih kontrasepsi suntik, sedangkan klien kedua memilih kontrasepsi pil. Dapat disimpulkan bahwa kedua klien mengetahui metode kontrasepsi dan memilih untuk menggunakan salah satu metode kontrasepsi setelah dilakukan pendidikan kesehatan.
\end{abstract}

Kata Kunci : Pendidikan Kesehatan, Primipara, Metode Kontrasepsi

\begin{abstract}
Family planning programs enable the government to reduce fertility rates and improve health, welfare, human right and education. In some develop countries used of contraception was still limited. Health education is one way to increase knowledge about contraception. The purpose of the research was to know the description of the application of health education method about contraception to primiparous mother in Dahlia room. The Research used decriptive design with nursing process. The research was conducted in May 2019 with 2 two primiparous mothers as the respondent, and used maternity nursing assestment and SAP. Data were presented in tabular form accompanied by narrative explanation. The respondents did not know about contraceptive method before gived the health education. But, after the respondents gived the health education, they were understood the contraceptive method. The first client choose injection contraception the second client choose pill contraceptive. Can be concluded that both of clients know the contraceptive method and choose to use one of the contraception methods after health education.
\end{abstract}

Keywords: Health Education, Primiparous, Contraception Method

\section{PENDAHULUAN}

Negara berkembang dengan jumlah penduduk terbanyak keempat di dunia adalah Indonesia. Salah satu upaya yang dilakukan pemerintah Inodnesia dalam menekan laju pertambahan penduduk di Indonesia ialah dengan program Keluarga Berencana (KB). Ada berbagai macam alat kontrasepsi yang dapat digunakan oleh Psangan Usia Subur (PUS) dalam program KB tersebut, antara lain IUD, kondom bagi pria dan wanita, tubektomi dan vasektomi, suntik, pil, dan implan. Masing-masing alat kontrasepsi ini memiliki keunggulan dan kekurangan. Beragam macam jenis alat kontrasepsi ini tidak jarang membuat PUS bingung 
untuk menentukan mana alat kontraspsi yang tepat dan cocok untuk digunakan.

Berdasarkan Survey 'Contraception: Getting the Facts Right' pada 9 negara seperti China, Korea Selatan, Thailand, Singapura, Indonesia, India, Pakistan, Taiwan dan Malaysia menyatakan bahwa sekitar 30\% koresponden di Asia mendapatkan informasi yang salah dan tidak akurat tentang kontrasepsi.

Profil Kesehatan Indonesia tahun 2016 menjelaskan bahwa di Indonesia sendiri tercatat memiliki 48.536.690 PUS dengan peserta KB aktifnya berjumlah 36.306 .662 dan 6.663 .156 tercatat sebagai peserta KB baru. Adapun metode kontrasepsi yang paling banyak digunakan di Indonesia adalah metode suntik sebanyak 47,96 \% dan yang paling sedikit digunakan ialah metode operasi pria sebanyak $0,64 \%$ (Kemenkes RI, 2016).

Data tersebut menunjukkan bahwa masih terdapat PUS yang tidak mengikuti program KB. Tingkat pengetahuan dan pemahaman PUS biasanya menjadi salah satu alasan yang mendorong keinginan untuk menggunakan alat/metode kontrasepsi tertentu. Lasut dkk (2014) dalam penelitian berjudul Pengaruh Pendidikan Kesehatan terhadap Pengetahuan PUS tentang Alat Kontrasepsi Implan di Wilayah Kerja Puskesmas Nuangan Bolaang Mongondow Timur menyimpulkan bahwa ada pengaruh pendidikan kesehatan terhadap pengetahuan PUS tentang kontrasepsi implan, dimana terjadi peningkatan pengetahuan setelah diberikan pendidikan kesehatan.

Pendidikan kesehatan dapat mempengaruhi pengetahuan. Kegiatan ini merupakan bagian dari promosi kesehatan yang bertujuan untuk memperbaiki kesadaran serta meningkatkan pengetahuan dan keterampilan. Ibu Primipara sangat membutuhkan paparan informasi tentang jenis metode kontrasepsi yang tepat yang akan digunakan setelah proses

persalinan dan menyusui. penelitian ini bertujuan untuk mengetahui gambaran penerapan metode pendidikan kesehatan tentang kontrasepsi pada Ibu primipara di ruangan Dahlia RSD Liun Kendage Tahuna. Setelah penelitian diharapkan juga bagi ibu primipara dapat memutuskan untuk memilih metode kontrasepsi yang akan digunakan.

\section{METODE PENELITIAN}

Desain Studi menggunakan rancangan deskriptif dengan pendekatan proses keperawatan. Subyek studi kasus yaitu 2 orang klien dengan kriteria ibu primipara yang menggunakan metode kontrasepsi dan bersedia menjadi responden. Variabel penelitian ialah penerapan pendidikan kesehatan tentang metode kontrasepsi. Penelitian ini telah dilaksanakan pada bulan Mei 2019 di ruangan Dahlia RSD Liunkendage Tahuna. Instrumen penelitian menggunakan format pengkajian keperawatan maternitas, SAP (Satuan Acara Penyuluhan), dan leaflet tentang metode kontrasepsi. Data disajikan dalam bentuk tabel dan dibuat secara narasi.

\section{HASIL PENELITIAN}

Tabel 1. Distribusi responden berdasarkan karakteristik di ruangan Dahlia RSD Liun Kendage Tahuna Tahun 2019

\begin{tabular}{ccc}
\hline Responden & Usia & Pendidikan \\
\hline Klien 1 & 39 tahun & S1 \\
Klien 2 & 34 tahun & DIII \\
\hline
\end{tabular}

Tabel ini menunjukkan perbedaan usia responden, dimana usia klien 1 masuk kategori usia resiko untuk melahirkan sedangkan klien 2 masih masuk dalam usia aman untuk melahirkan, selain itu terdapat perbedaan tingkat pendidikan, dimana klien 1 memiliki pendidikan tertinggi yaitu $\mathrm{S} 1$. 
Tabel 2. Hasil pedidikan kesehatan dengan metode kontrasepsi di ruangan Dahlia RSD Liun Kendage Tahuna

\begin{tabular}{|c|c|}
\hline Responden & Evaluasi \\
\hline Klien 1 & $\begin{array}{l}\text { Klien belum mengetahui } \\
\text { tentang penggunaan } \\
\text { kontrasepsi, keuntungan dan } \\
\text { kerugiannya, namun setelah } \\
\text { diberikan pendidikan } \\
\text { kesehatan tentang kontrasepsi, } \\
\text { klien dapat mengetahui dan } \\
\text { mengambil keputusan untuk } \\
\text { menggunakan kontrasepsi } \\
\text { suntik. }\end{array}$ \\
\hline Klien 2 & $\begin{array}{l}\text { Klien belum mengetahui } \\
\text { tentang penggunaan } \\
\text { kontrasepsi, serta keuntungan } \\
\text { dan kerugiannya, namun } \\
\text { setelah diberikan pendidikan } \\
\text { kesehatan tentang kontrasepsi, } \\
\text { maka klien dapat mengetahui } \\
\text { dan mengambil keputusan } \\
\text { untuk menggunakan } \\
\text { kontrasepsi pil }\end{array}$ \\
\hline
\end{tabular}
pengetahuan setelah diberikan pendidikan kesehatan.

Tabel 3. Distribusi responden berdasarkan pilihan penggunaan $\mathrm{KB}$ pada responden di ruangan Dahlia RSD Liun Kendage Tahuna

\begin{tabular}{cc}
\hline Responden & Pilihan penggunaan KB \\
\hline Klien 1 & Suntik \\
Klien 2 & Pil \\
\hline
\end{tabular}

Tabel 3 menunjukkan setelah diberikan pendidikan kesehatan tentang metode kontrasepsi maka Klien 1 memilih menggunakan KB suntik dan Klien 2 memilih KB Pil.

\section{PEMBAHASAN}

Penelitian ini dilakukan dengan memberikan penyuluhan kepada masing-masing pasien tentang metode kontrasepsi, baik kekurangan maupun kelebihannya. Penyuluhan yang diberikan dilakukan menggunakan leaflet dan alat peraga kontrasepsi sebagai pengenalan kepada pasien karena kedua pasien tersebut belum mengetahui dengan jelas macammacam kontrasepsi yang ada serta dapat memilih kontrasepsi yang akan digunakan saat pulang dari rumah sakit. Metode yang digunakan dalam penyuluhan ialah ceramah dan tanya jawab sehingga memungkinkan terjadinya interaksi secara aktif antara perawat dan pasien sehingga pasien dapat memperoleh informasi yang lebih tentang metode kontrasepsi. Alat peraga berupa alat kontrasepsi juga membantu menstimulus penglihatan dan pendengaran sehingga secara tidak langsung dapat meningkatkan penerimaan informasi bagi pasien/responden.

Setelah diberikan pendidikan kesehatan, terjadi peningkatan pengetahuan dari tidak tahu menjadi tahu, sehingga kedua pasien akhirnya memilih jenis kontrasepsi, yaitu kontrasepsi suntik bagi pasien 1 dan kontrasepsi pil bagi pasien 2. Hasil penelitian Putri dkk (2018) menunjukkan tingkat pengetahuan ibu $(\mathrm{p}=0,01)$ berhubungan tingkat pemilihan kontrasepsi pada pasangan usia subur (PUS). Pengetahuan merupakan hasil "tahu" dan terjadi setelah seseorang mengadakan penginderaan terhadap suatu obyek tertentu. Pengetahuan atau kognitif merupakan domain yang sangat penting untuk terbentuknya tindakan seseorang, yaitu termasuk partisipasi dalam suatu kegiatan (Notoatmodjo, 2012). Salah satu hal yang mempengaruhi pengetahuan ialah informasi, kemudahan untuk memperoleh informasi, membantu mempercepat seseorang memperoleh pengetahuan yang baru (Mubarak, 2011).

Hal ini dibuktikan dengan penelitian Kaseuntung dkk (2015) tentang pengaruh penyuluhan kesehatan terhadap pengetahuan wanita usia subur (WUS) dalam pemilihan kontrasepsi di Desa Kalama Darat Kecamatan Tamako Kepulauan Sangihe didapatkan hasil bahwa nilai $\mathrm{p}=0,000$ sehingga ada pengaruh penyuluhan kesehatan terhadap pengetahuan wanita usia subur dalam pemilihan kontrasepsi.

Hasil penelitian Nurlaela dan Harahap (2013) menunjukkan bahwa pengetahuan dan sikap ibu primipara sangat berpengaruh dalam menentukan penggunaan kontrasepsi yang tepat. Dengan adanya informasi yang diberikan kepada ibu primipara maka 
akan lebih mudah memilih kontrasepsi sesuai yang diinginkan. Penelitian Sukriani dan Wulandari (2012) menyimpulkan bahwa ada hubungan yang bermakna antara tingkat pengetahuan ibu primipara tentang alat kontrasepsi dengan pemilihan alat kontrasepsi di wilayah kerja Puskesmas Tambakaji Kota Semarang dengan nilai $\mathrm{p}=0,006$. Dalam penelitian tersebut juga diperoleh hasil bahwa sebagian besar ibu primipara mempunyai pengetahuan yang baik tentang alat kontrasepsi. Hal tersebut ditunjukkan dengan tingginya animo masyarakat dalam menjalankan keluarga berencana dengan memanfaatkan alat kontrasepsi yang telah disediakan oleh pihak puskesmas.

Pengetahuan dari kedua responden menyatakan bahwa selama ini tidak mengetahui tentang kekurangan dan kelebihan kontrasepsi baik itu suntik, kondom, pil, spiral, maupun implan kedua responden hanya mengetahui yang namanya kontrasepsi fungsinya untuk mencegah kehamilan. Pengetahuan memungkinkan seseorang untuk dapat memecahkan masalah yang dihadapinya dimana pengetahuan tersebut diperoleh dari pengalaman langsung maupun pengalaman orang lain (Notoatmodjo, 2012).

Kamariyah (2015) menyatakan bahwa semakin lama akseptor menggunakan KB suntik maka keberlangsungan pengguna KB suntik semakin baik, begitu pula pengetahuan individu seseorang menjadi akseptor KB. Semakin tinggi tinggi tingkat pengetahuan seseorang maka tingkat kepatuhan untuk melakukan penyuntikan ulang sesuai jadwal juga semakin baik.

Hasil penelitian ini menunjukkan bahwa 2 reponden berbeda pilihan tentang penggunaan kontrasepsi dimana responden yang pertama memilih kontrasepsi suntik untuk mencegah kehamilan dan lebih paham tentang kontrasepsi suntik dibandingkan kontrasepsi lainnya, sedangkan pada responden yang kedua memilih untuk menggunakan kontrasepsi pil untuk mencegah kehamilan, responden yang kedua memilih pil sebagai alat kontrasepsi karena lebih muda penggunaannya dibandingkan dengan kontrasepsi yang lain meskipun menyadari bahwa jenis kontrasepsi ini membutuhkan tingkat kepatuhan untuk rutin meminum pil KB. Sebelum memutuskan memilih metode kontrasepsi, responden mengungkapkan ketidaktahuan tentang metode kontrasepsi, bagi dari segi keuntungan dan kerugian dari setiap jenis kontrasepsi yang ada, namun setelah diberikan pendidikan kesehatan tentang metode kontrasepsi, 2 orang responden tersebut kemudian menentukan metode kontrasepsi. Setiap WUS yang menggunakan kontrasepsi dilandasi keinginan yang jelas, yaitu menunda kehamilan, membatasi jumlah anak, atau memberi jarak memiliki anak. Menurut Kusumaningrum (2009), bahwa pilihan yang didasarkan dari informasi yang lengkap tentang kontrasepsi pada akhirnya akan menghasilkan pilihan metode kontrasepsi yang bersifat rasional.

Hal ini juga didukung oleh Penelitian Wahyuni dkk (2017), bahwa setelah diberikan pendidikan kesehatan tentang AKDR (Alat Kontrasepsi Dalam Rahim) pada 30 orang responden, 17 orang $(55,84 \%)$ diantaranya memiliki pengetahuan cukup dan 13 orang $(44,16 \%)$ memiliki pengetahuan yang baik. Hasil analisa dalam penelitian tersebut menyatakan bahwa responden yang mengalami peningkatan pengetahuan AKDR karena mendapatkan pendidikan kesehatan. Sebelum diberikan pendidikan kesehatan hanya 1 orang responden yang memiliki pengetahuan yang baik, kemudian setelah diberikan pendidikan kesehatan mengalami peningkatan menjadi 13 orang.

Pengetahuan seseorang dapat dipengaruhi beberapa hal, termasuk pendidikan. Karakteristik pendidikan dari 2 pasien responden. Responden 1 memiliki pendidikan sarjana dan responden 2 memiliki pendidikan D3. Pendidikan dapat menentukan mudah tidaknya seseorang memahami informasi yang diterima melalui pendidikan kesehatan/penyuluhan. Pada umumnya semakin tinggi pendidikan yang dimiliki seseorang, lebih terbuka untuk menerima hal yang baru dibandingkan dengan individu yang berpendidikan 
rendah (Mubarak, 2011). Selain pendidikan, usia seseorang juga mempengaruhi pengetahuan seseorang. Menurut Nursalam (2010), bahwa semakin dewasa usia seseorang maka akan berpengaruh terhadap tingkat pengetahuan yang dimiliki dan cara mendapatkan informasi tersebut.

\section{KESIMPULAN}

Kesimpulan pada penelitian ini adalah kedua klien mengetahui metode kontrasepsi dan memilih untuk menggunakan salah satu metode kontrasepsi setelah dilakukan pendidikan kesehatan. Dan disarankan Perawat sebagai petugas kesehatan di rumah sakit harus memberikan pendidikan kesehatan tentang metode kontrasepsi bagi ibu primipara di ruangan Dahlia.

\section{DAFTAR RUJUKAN}

Kamariyah Nurul. 2015. Tingkat pengetahuan Ibu Meneteki Mempengaruhi Jenis Kontrasepsi Suntik di Pustu Kangenan Pamekasan. Jurnal Ilmiah Kesehatan Volume 8 Nomor 1 e-ISSN 2477-3948, diakses di https://journal2.unusa.ac.id

Kaseuntung Christiana, Kundre Rina, dan Bataha Yolanda. 2015. Pengaruh Penyuluhan Kesehatan terhadap Pengetahuan Wanita Subur (WUSH) dalam Memilih Kontrasepsi di Desa Kalama Darat Kecamatan Tamako Kepulauan Sangihe. Journal Keperawatan Volume 3 Nomor 3 Agustus 2015 ISSN 2302-1152, diakses di https://ejournal.unsrat.ac.id

Kemenkes RI. 2016. Profil Kesehatan Indonesia, Jakarta: Kementerian Kesehatan Republik Indonesia.
Kusumaningrum R. 2009. Faktor-Faktor yang Memengaruhi Pemilihan Jenis Kontrasepsi yang Digunakan pada Pasangan Usia Subur. Universitas Diponegoro, diakses di https://eprints.undip.ac.id

Lasut Veby Monica, Palandeng Henry, dan Bidjuni Hendro. 2014. Pengaruh Pendidikan Kesehatan Terhadap Pengetahuan PUS Tentang Alat Kontrasepsi Implan di Wilayah Kerja Puskesmas Nuangan Bolaang Mongondow Timur. Diakses di https://media.neliti.com

Mubarak W.I. 2011. Promosi Kesehatan. Jakarta : Salemba Medika.

Notoatmodjo, S. 2012. Metodologi penelitian Kesehatan. Jakarta : Rineka Cipta.

Nurlaela, D dan Harahap, D. 2013. Gambaran Pengetahuan dan Sikap Tentang Metode Kontrasepsi pada Primipara. Program Studi Sarjana Ilmu Keperawatan Fakultas Ilmu Keperawatan: Universitas Indonesia, Depok, diakses di https;//.lontar.ui.ac.id tanggal 4 Juli 2019.

Nursalam. 2010. Konsep dan Penerapan Metode Ilmu Keperawatan. Jakarta : Salemba Medika.

Putri Ni Put Ditadiliyana, Pradnyaparamitha, dan Ani Luh Seri. 2018. Hubungan Karakteristik, Tingkat Pengetahuan dan Sikap Ibu dengan Pemilihan Alat Kontrasepsi pada Pasangan Usia Subur di Kecamatan Sidemen Kabupaten Karangasem Bali. Jurnal Medika Udayana Volume 8 Nomor 1 2019. 
41 Jurnal Ilmiah Sesebanua, Volume 5, Nomor 1, Maret 2021, hlm. 36-41

Sukriani dan Wulandari Priharyanti. 2012. Jurnal: Hubungan Tingkat Pengetahuan Ibu Tentang Alat Kontrasespsi dengan Pemilihan Alat Kontrasepsi pada Ibu Primipara di Wilayah Kerja Puskesmas Tambakaji. Diakses di https://jurnal.unismus.ac.id tanggal 4 Juli 2019.
Wahyuni Sri, Nurmalia Resyana, dan Mintarsih Wiwin. 2017. Efektifitas Pendidikan Kesehatan terhadap Peningkatan Pengetahuan Wanita Usia Subur tentang Alat Kontrasepsi Dalam Rahim di Desa Cilampunghilir Kecamatan Padakembang Kabupaten Tasikmala. Jurnal Riset Kebidanan Indonesia Volume 1 Nomor 1 Juni 2017 e-ISSN 2615-562. 